Collaboration, communication, support and relationships in the context of ecommerce within the franchising sector

\author{
Zhanna Kremez \\ Griffith Business School, Griffith University \\ jannakremez@gmail.com
}

\author{
Lorelle Frazer \\ USC Business School, University of the Sunshine Coast \\ 1frazer@usc.edu.au \\ Sara Quach \\ Department of Marketing, Griffith Business School \\ s.quach@griffith.edu.au \\ Park Thaichon \\ Department of Marketing, Griffith Business School \\ p.thaichon@gmail.com
}




\title{
Collaboration, communication, support and relationships in the context of ecommerce within the franchising sector
}

\begin{abstract}
This research aims to investigate how ecommerce influences elements of the franchising sector that have adopted an ecommerce strategy. A multiple case-study approach was selected to gain a comprehensive understanding of franchise organisations following implementation in their traditional service or retail businesses. The findings covered, but were not limited to, (a) franchise relationships, (b) franchisor leadership, (c) communication at the franchise network level, (d) collaboration with franchisees, and (e) training and support. The paper offers meaningful outcomes including (a) a framework for franchisee communication and participation, and (b) a model for franchisee acceptance and readiness for change, as well as effective communication in the franchise network. Finally, from the interviews conducted with franchise practitioners, certain practical recommendations have been made that will serve the franchise sector.
\end{abstract}

Keywords: ecommerce; ecommerce in franchising; franchise relationships; relationship marketing; training and support; franchisor leadership.

Article Classification: Practitioner Paper 


\section{Overview}

Ecommerce has become an inherent part of many modern businesses. However, combining the digital interchange of goods or commodities and franchising may encourage a conflict of interest, which requires careful management (Rao \& Frazer, 2010; Terry, 2002). While it appears relatively easy for traditional retailers to enter the online transactional space, it is increasingly difficult for franchises to participate due to a number of complicating factors pertaining to potential encroachment and franchisee acceptance (Emerson, 2010); indeed, some franchise networks even resort to litigation to solve their conflicts over digital channels (Knack \& Bloodhart, 2001). Therefore, this research aims to investigate the influences of business-to-consumer (B2C) ecommerce on collaboration, communication, franchisee support and franchise relationships.

Researchers such as Cliquet and Voropanova (2016) and Perrigot, Basset and Cliquet (2017) have highlighted the scarcity of literature investigating how businesses have embraced ecommerce as an essential part of their franchising operations. Besides, offering services online has become an increasingly useful and complementary channel for businesses to market their products (Perrigot \& Pénard, 2013; Tagashira \& Minami, 2016), geared towards increasing recognition and awareness, customisation and personalisation, and further optimising supply-chain efficiency (Trinh, Anesbury \& Driesener, 2017). In addition, the interaction between consumer needs and online retail management remains dynamic. As consumers possess increasingly distinct characteristics, needs and wants, retailers must utilise different strategies to address an ever-changing market, including the management of an online platform that assists consumers in their information search and evaluation stages (Kaushik et al., 2018; Nisar \& Prabhakar, 2017). Hence, ecommerce is a business strategy that permits a wider reach to different consumers (Chumnumpan \& Shi, 2019; Di Fatta, Patton \& Viglia, 2018). 
Conversely, several recent studies in franchising have focused on consumer behaviour (Weaven et al., 2018) as well as a range of related issues concerning franchising relationships. This includes expectations after opening a part-time franchising business (Thaichon et al., 2019), women in franchisees (Thaichon et al., 2018), self-employment in franchising (Weaven et al., 2019), the effect of learning and development on business performance (Timms et al., 2019), and work-life balance in small businesses (Young et al., 2019). Yet, there remains limited research examining the relational context of ecommerce within the franchising sector. Investigating how successful franchise networks have incorporated ecommerce into their operations and marketing, this paper can otherwise uncover the best practices in the field and develop an ecommerce framework for franchising, where franchisor-franchisee relationships are the cornerstone of any digital marketing strategy. Importantly, reference herein to successful ecommerce implementation is concerned with determining the quality of franchise relationships. Therefore, the definition of success is measured in terms of franchisee acceptance and satisfaction. This approach helps to avoid conflict with franchisees, which can result in a costly and time-consuming process for franchisors and further prove potentially detrimental to the reputation of an entire brand. In addition, this research addresses the role of ecommerce in franchise relationships, specifically regarding how franchisees form effective implementation strategies, as well as their perception of ecommerce in business.

\section{Literature review}

\subsection{Ecommerce}

Franchising has shown considerable growth in recent years and in developed countries such as the United States (US) (Seo, 2016), United Kingdom (UK) (Watson, Kirby \& Egan, 2002), France (Cliquet \& Voropanova, 2016) and Australia (Young et al., 2019). In fact, Watson et al. (2002) claimed that franchising accounts for approximately one- third of 
all retail sales. Conversely, ecommerce has grown tremendously over the past decade in many business sectors, including franchising (Kremez et al., 2019; Perrigot \& Pénard, 2013). These global trends of growth have prompted franchisors to reconsider their otherwise reserved approach towards the online offering of products and services (Cliquet \& Voropanova, 2016; Frazer et al., 2014). Besides, the main characteristics of ecommerce that differentiate the system from traditional commerce include usage of internet services, virtual shopping platforms, online payment systems, virtual customer communications and interactions, and indirect product distribution (DeLone \& McLean, 2014).

Ideal ecommerce strategies emphasise the integration of both online and offline networks (Cui \& Pan, 2015). Research to date has found that ecommerce actively supports business processes, particularly in expanding the market, increasing supply chains and operational efficiency, and serving consumers in multiple geographical locations (Chau, 2003; DeLone \& McLean, 2014; Hua et al., 2019). Additionally, given the changing nature of the retail industry and the advent of ecommerce, the practice can be viewed as an important channel for franchising development (Perrigot \& Pénard 2013; Watson et al., 2002).

\subsection{Ecommerce in franchising}

Several studies highlight the benefits of online platforms and ecommerce in franchising. Notably, Dixon and Quinn's (2004) analysis of franchise websites indicates that many franchisors use online services for communication (with franchisees) and marketing purposes (for customers). Indeed, previous research has shown that network size has a positive effect on implementation as well as subsequent adoption of ecommerce in practice (Perrigot \& Pénard, 2013). Some additional benefits include online ordering and payment options (Dixon \& Quinn, 2004); cheaper costs and more effective organisational culture (Shah Alam, 2009); favourable relationships between online consumers and e-vendors (Wang et al., 2016); better function or options for product variety; product customisation, convenience or price 
(Chaparro-Peláez et al., 2016); and more transparent service knowledge and information (Choshin \& Ghaffari, 2017). In turn, some of these factors could lead to superior customer satisfaction (Choshin \& Ghaffari, 2017); customer commitment, trust and perceived value (Thaichon et al., 2014); improved service quality and stronger customer loyalty (Quach et al., 2016). Hence, both ecommerce and franchising are considered prominent business strategies.

Moreover, firms franchise their operations to rapidly grow their market, expand business, diversify and improve performance (Watson et al., 2002; Wu, 2015). In franchising, there is an established idea or business model franchisors create, which is bought, adopted and operated by franchisees (Peterson \& Dant, 1990). Although franchising networks will involve multiple stakeholders, it is necessary for the system to remain consistent across franchise holders (Perrigot et al., 2013). Hence, its operations will require advanced communications between participants to ensure absolute consistency (Cliquet \& Voropanova, 2016; Perrigot \& Penard, 2013).

A small group of literature has studied the crossover between franchising and ecommerce, including the strong offline elements of franchising (such as geographical location and the legal system), which affect the implementation of ecommerce in the system. For example, Chau (2003) mentioned ecommerce as a potential 'game changer' in franchising, while Dixon and Quinn (2004) argued that ecommerce is not fully applied in the system since franchisors use only brochure-type websites, cloud storage and online communication systems instead of selling their B2C products online. Recent work by Dorward et al. (2017) supports Chau's (2003) prediction by highlighting the augmented reality game Pokémon Go as one example of extending an already successful media and gaming franchise. Despite the extent of ecommerce adoption in franchising, the practice itself supports the franchise system in several aspects. 
First, ecommerce leverages communication between parties in a franchising system (Chau, 2003; Perrigot et al., 2013). Franchise firms use websites to deliver information to franchisors, other (and potential) franchisees and individual customers (Chau, 2003; Dixon \& Quinn, 2004; Kremez et al., 2019). For example, world-leading franchisors such as Subway and 7-Eleven offer step-by-step information on their websites detailing how to become a franchisee.

Second, following advanced communications, ecommerce assists in maintaining uniformity in the franchising system (Perrigot et al., 2013). According to the intellectual and industrial property law in most countries, a franchise system is regarded as an intellectual property. Therefore, a franchisee must maintain consistent operating practices that uphold the franchise brand identity. Through an ecommerce system, knowledge (such as price and product information) spreads rapidly in a real time. Indeed, this could assist franchisors in delivering news quickly to franchisees, but there remain concurrent challenges in maintaining operational uniformity due to different resources and (digital) capabilities among network members.

Third, ecommerce plays important roles in customer relationship management. There are two types of customers in a franchise: organisational (franchisee) and individual customers. Ecommerce facilitates communications (Chau, 2003) while the effective knowledge-sharing between franchisor and franchisees improves the latter's satisfaction and compliance (Lee, 2017). Recent research in franchise hotels indicates that ecommerce determines the effect of hotel-customer loyalty programs on room revenue (Hua et al., 2019). Given that franchise hotels have comprehensive customer databases, ecommerce can assist in targeting specific market segments with customised product offerings (Hua et al., 2019), while maintaining communications between hotels and customers. Collectively, the studies reviewed in this paper seem to suggest a pertinent role of ecommerce in franchising. The 
evidence presented proposes that its communication feature, in particular, provides additional support in a franchise system and (thus) warrants further investigation.

Yet, how organisations use consumer data underwent change in 2018 following the introduction of a new European privacy law that restricts the way personal data are collected and used (Wachter \& Mittelstadt, 2019). The rule, known as the General Data Protection Regulation, focuses on ensuring that users know, understand and consent to the data collected about them. Under this new law, companies must be clear and concise about their collection methods and use of personal data, further spell out why data are being collected and explicate whether that information will be used to create profiles of people's actions and habits. As the law protects only individuals in 28 member countries of the European Union-even if the data were processed elsewhere (Tiku, 2018) - this inevitably affects every company worldwide that deals with European citizens.

\subsection{Change management: Ecommerce in franchising}

Change is a constant element that affects all organisations (Todnem By, 2005) including franchise networks. Inevitably, the introduction of ecommerce into franchise systems calls for effective change management and communication within and across organisations. Most literature in both sectors assumes an organisational standpoint, where the main stakeholder groups are managers and employees, which to some extent can inform franchisor-franchisee relations. As such, two dominant models for change management are considered in this section: Lewin's (1999) force-field analysis and Kotter's (1996) eight-step change model, along with other literature in the domain.

According to Lewin (1999), any organisation is a system in a dynamic balance ('equilibrium') between two opposing forces: driving forces (those promoting change) and restraining forces (those seeking to maintain the status quo). Successful implementation of change depends on driving forces exceeding restraining forces to shift the equilibrium. Here, 
force-field analysis would suggest that we investigate the balance of power involved in the situation requiring change and further identify the most important stakeholders, 'target groups', opponents and allies concerned-including the different ways to influence each market (Lewin, 1999). In addition, Lewin (1947) argued that during a change process, three stages of unfreezing, moving and refreezing are experienced. Based on this premise, researchers have attempted to identify a set of actions that change agents could take to minimise resistance and help organisations and individuals undergoing transition. For example, Coch and French (1948) explored the effect of employee participation on productivity and satisfaction during organisational change. They found that a greater degree of participation led to higher employee satisfaction, enabling them to adapt more quickly to new production goals (Coch \& French, 1948; Holt et al., 2007). This proposition is further explored in this research.

Similarly, Kotter's (1996) model suggests that eight steps should be taken to ensure successful change. These are as follows: (1) inciting a sense of urgency for change should be increased by inspiring people to move; (2) a team of guiding people with the right emotional commitment and right skills should be brought together to (3) establish a vision and strategy to drive change; (4) emphasis should be placed on involvement and communication, and technological opportunities should be exploited; (5) action needs to be empowered, obstacles removed and managerial support provided; then, (6) visible and attainable goals should be set with corresponding rewards; (7) determination and persistence should also be encouraged, as well as ongoing progress reporting, with future milestones further highlighted; finally, (8) the value of successful change should be reinforced (Kotter, 1995, 1996).

Additionally, Nelissen and van Selm (2008) found that satisfaction with management communication leads to positive responses to organisational change among employees. Indeed, the adequacy of change-related communication was found to be the main predictor of 
change readiness (McKay et al. 2013). Therefore, organisations should focus on improving employee satisfaction with how management communicates about objectives and consequences of change, as it is a key determinant of resultant positivity (Nelissen \& van Selm, 2008).

In addition, de Ridder (2004) argued that high-quality internal communication may be important in encouraging a supportive attitude towards strategic direction. The author discusses trust in management as a key player in this process. To create trust, managers are required to explicitly communicate the goals of change and remain open about potential issues (de Ridder, 2004). According to Elving's (2005) model (used also in this research), communication during the change process can be conducted with two purposes in mind: inform and create community spirit. When undertaken successfully, communication can increase readiness for change and decrease the chance of resistance (Elving, 2005). Thus, it is proposed that defiance in this context can be reduced and, therefore, franchisee acceptance can increase through the broad engagement of franchisees (as key stakeholders), the provision of appropriate education and training, and careful consideration of franchisor relationships. In this framework, clear, consistent and effective communication is the cornerstone for success.

\section{Methodology}

\subsection{Approach}

A multiple case-study approach was selected for this research to gain a comprehensive understanding of several franchise organisations (Eisenhardt, 1989). This enabled the researchers to study their ecommerce strategies from multiple stakeholders' perspectives, including franchisors, franchisees and customers. It further allows for investigation of contemporary phenomena within a real-life, bounded context using multiple sources of evidence (Merriam, 2009; Yin, 2009). Case study research has added use when the research 
objectives are to explain current situations and to explore the 'why' and 'how' (Yin, 2009) as in this study. Meanwhile, using multiple examples can enhance precision, validity or generalisability, and stability of the findings (Merriam, 2009; Miles \& Huberman, 1994). This is because the interaction between a phenomenon and its context is best understood through in-depth case studies (Dubois \& Gadde, 2002). As this research is primarily concerned with studying $a$ phenomenon-that is, the implications of ecommerce in franchising - and not a particular case as such, a selection of franchise systems were chosen as instrumental cases that collectively provide insight on the issue (Stake, 1994). The examples themselves are of a secondary nature and serve to facilitate understanding of the research problem (Stake, 1994). In addition, the common use of case studies and case analysis in franchising research (e.g., Altinay \& Brookes, 2012; Altinay et al., 2013, 2014; Brookes, 2014; Brookes \& Altinay, 2011; Doherty, 2009; Forte \& Carvalho, 2013) could be explained by the limited availability of secondary data, as many of the franchisors and franchisees are private firms.

\subsection{Sampling}

The cases selected represent a larger population of examples-that being franchise organisations in Australia employing ecommerce strategies in their traditional service or retail businesses. The best possible explanations of these phenomena were sought and, therefore, viewed as opportunities for close study (Yin, 2009). Thus, purposeful sampling was used (Eisenhardt, 1989; Huberman \& Miles, 1994).

The first selection criterion regards the cases' leading position in ecommerce within their industry. Their focus on franchisee satisfaction was important to ensure a collection of franchisors that exhibited best practice in the sector in terms of franchisor-franchisee relations. Additionally, mature systems were chosen since Rao and Frazer (2010) found that mature Australian franchisors (older and larger systems) had better-developed online 
strategies. The representativeness of these cases within the research context (ecommerce in franchising) was deemed important (Stake, 1994). Therefore, those selected were averaging within the sector 5 per cent of their total sales online (Frazer, Weaven \& Bodey, 2012; Frazer, Weaven \& Grace, 2014) and had not experienced a dramatic increase in returns through their digital channel (e.g., Dominos) or were not purely trading online (e.g., Aussie Farmers Direct).

In addition, the two cases were selected due to their similarities on key organisational dimensions. They were both mature and large franchise organisations, meeting the desired criteria. Founded in the early 1990s, both companies have since experienced substantial growth in franchise units and established themselves as industry leaders. International operations were also similarly conducted in two international English-speaking markets, and both offered a mix of retail and service industries (i.e., both cases offer a physical service and hold retail outlets). Thus, each faced the challenges of traditional retail networks as well as those of service networks. For these reasons, the businesses were easily comparable and differences in their ecommerce strategies were identifiable. Table 1 details and explains the criteria used for selecting cases for this research.

Table 1: Criteria for Case Selection and Characteristics of Chosen Cases

\begin{tabular}{llll}
\hline $\begin{array}{l}\text { Criteria for case } \\
\text { selection }\end{array}$ & Description & Case 1 & Case 2 \\
\hline System age & $\begin{array}{l}\text { Mature systems (over 10 } \\
\text { years) (FA survey, 2014, } \\
\text { p. 30) }\end{array}$ & Founded in 1993 & Founded in 1992 \\
System size & $\begin{array}{l}\text { Large systems (more than } \\
\text { 50 total units) (FA survey, }\end{array}$ & $\begin{array}{l}\text { 106 retail service } \\
\text { centres (self- } \\
\text { 2014, p. 35) }\end{array}$ & $\begin{array}{l}\text { 70 retail centres } \\
\text { and 250 mobile } \\
\text { (self-reported data, }\end{array}$ \\
$\begin{array}{llll}\text { Plural form or pure- } \\
\text { form franchises }\end{array}$ & $\begin{array}{l}\text { Franchise organisations } \\
\text { with a minimal } \\
\text { percentage of company- } \\
\text { owned units }\end{array}$ & $\begin{array}{l}\text { One company- } \\
\text { owned unit }\end{array}$ & $\begin{array}{l}\text { No company- } \\
\text { owned units, 100\% } \\
\text { franchised }\end{array}$ \\
$\begin{array}{l}\text { Level of franchisee } \\
\text { sophisticated methods of } \\
\text { involvement }\end{array}$ & High & High \\
\hline
\end{tabular}




\begin{tabular}{|c|c|c|c|}
\hline Industry & Mixed service and retail & $\begin{array}{l}\text { Transport, postal } \\
\text { and warehousing }\end{array}$ & $\begin{array}{l}\text { Administration and } \\
\text { support services }\end{array}$ \\
\hline $\begin{array}{l}\text { Percentage of } \\
\text { online sales }\end{array}$ & $\begin{array}{l}\text { Percentage of sales } \\
\text { through an online channel } \\
\text { from the total number of } \\
\text { sales }\end{array}$ & $\begin{array}{l}\text { Approximately } \\
5 \%\end{array}$ & Approximately 5\% \\
\hline $\begin{array}{l}\text { Level of } \\
\text { ecommerce } \\
\text { development and } \\
\text { strategy success }\end{array}$ & $\begin{array}{l}\text { Established and } \\
\text { successful ecommerce } \\
\text { strategy }\end{array}$ & Yes & Yes \\
\hline Brand recognition & $\begin{array}{l}\text { Established brand in its } \\
\text { industry }\end{array}$ & Yes & Yes \\
\hline $\begin{array}{l}\text { International } \\
\text { operations }\end{array}$ & $\begin{array}{l}\text { Franchising outside of } \\
\text { Australia }\end{array}$ & Yes (NZ and UK) & Yes (NZ and US) \\
\hline
\end{tabular}

New Zealand (NZ)

The data acquired for each case consist of interviews with four franchisees and one or two interviews with the franchisor. In total, five interviews were conducted for Case 1, and six were conducted for Case 2. The franchisor representatives were selected in both cases for their involvement in project managing ecommerce implementation- that is, acting as change agents and communicating with franchisees about introducing ecommerce into the system. Interviewees were also actively participating in the training and support of franchisees as an ecommerce strategy was being integrated into their marketing channels and instore environments.

Next, interviews were conducted with four franchisees in each case, with participants selected according to specific criteria (see Table 2). The goal for including these benchmarks was to achieve as much variability as possible between the franchisees interviewed. Participants were a mixture of single-unit franchisees (SUFs) and multi-unit franchisees (MUFs), with half of the total sample in both cases currently serving on the Franchise Advisory Council (FAC). Their geographical location varied from CBDs and suburban areas to regional areas located across different states in Australia.

An additional dimension was achieved through interviewing sector experts regarding ecommerce in franchising. Participants were asked to reflect on their experiences with 
franchisor clients when their franchise set forth to incorporate ecommerce strategies into their traditional business model. The interviews were unstructured and respondents were prompted to explain further on areas of interest to the research. In total, seven experts were interviewed, including three franchise consultants, two internet and digital media consultants (with experience in franchising), and two franchise lawyers.

Table 2: Criteria for Franchisee Selection

\begin{tabular}{|c|c|}
\hline Criteria for selecting franchisees & Description \\
\hline One FAC member (currently) & $\begin{array}{l}\text { A current FAC member involved with the } \\
\text { brand and actively takes part in FAC's life; } \\
\text { they are also familiar with the FAC structure } \\
\text { and processes }\end{array}$ \\
\hline $\begin{array}{l}\text { One FAC member (at the time of ecommerce } \\
\text { implementation) }\end{array}$ & $\begin{array}{l}\text { A FAC member at the time of ecommerce } \\
\text { strategy implementation (very involved and } \\
\text { knowledgeable about the process) }\end{array}$ \\
\hline Number of years in the system & $\begin{array}{l}\text { Not just experienced franchisees or new } \\
\text { franchisees }\end{array}$ \\
\hline MUF & $\begin{array}{l}\text { At least one SUF must be included in the } \\
\text { sample }\end{array}$ \\
\hline SUF & $\begin{array}{l}\text { At least one MUF must be included in the } \\
\text { sample }\end{array}$ \\
\hline Variety in territorial position & $\begin{array}{l}\text { Diversity as to different states in Australia as } \\
\text { well as demographic density (CBD, } \\
\text { suburban, rural) }\end{array}$ \\
\hline One that embraced ecommerce & $\begin{array}{l}\text { A participant that embraced ecommerce } \\
\text { initially }\end{array}$ \\
\hline One that was sceptical of ecommerce & $\begin{array}{l}\text { A participant that did not embrace } \\
\text { ecommerce initially and was sceptical about } \\
\text { its benefits for the system }\end{array}$ \\
\hline One that was undecided about ecommerce & $\begin{array}{l}\text { A participant that was neither for nor against } \\
\text { ecommerce, and did not have a strong } \\
\text { opinion about the practice }\end{array}$ \\
\hline
\end{tabular}

\section{Results and discussion}

\subsection{Franchise relationships}

\subsubsection{Franchisor: Franchisee relationships}

Although franchise relationships constitute a central part of this research, participants, when asked directly about the influence of this change/innovation on franchisor-franchisee 
relations, mostly agreed that it had no direct effect. In general, they did not discuss these affiliations when prompted, but rather spoke on other underlying concepts relating to relationships, such as trust, franchisor leadership and the challenge of introducing innovation (i.e., ecommerce) into their networks. This included their perspectives on change in their own sphere and in the business world in general.

Trust in franchisor integrity and franchisor competence is a determinant of healthy franchising relationships (Altinay \& Brookes, 2012; Altinay, Brookes, Madanoglu \& Aktas, 2014; Davies, Lassar, Manolis, Prince \& Winsor, 2011; Rosado-Serrano \& Paul, 2018; Rosado-Serrano, Paul \& Dikova, 2018). Davies et al. (2011) explained the contingencies that arise from trust in franchise systems due to the mutual interdependence of a franchisor and its franchisees and asymmetrical control. In this bond, franchisees rely on their franchisor for both promotional support and managerial support, which together relates to training and process design (Davies et al., 2011). Therefore, trust is created when a franchisor can demonstrate both the competence to deliver these expectations and the ability to do so with integrity.

The findings of this research show that franchisor competence is demonstrated in both cases, with evidence from franchisee interviews supporting a high level of trust in franchisor competence. For example, one participant noted that their franchisor 'is very strong on the online side, and marketing in general' (CS2 Franchisor 3). However, with regard to franchisor integrity, the findings show that both cases could improve in this area. In particular, meeting time lines relates to integrity and influences trust negatively when they are exceeded (as has occurred according to respondents in both cases). Further, from prior research (Kremez, 2015) it was evident that the design and enactment of ecommerce usually involved more time than initially estimated. Therefore, it is proposed that allowing sufficient 
time for ecommerce implementation and keeping to agreed schedules would successfully mediate the risk of trust being affected.

Relationships are also based on the confidence that a franchisor has the sufficient knowledge to act in the best interest of a system. Competence can be demonstrated through leadership, which was another prominent theme discussed during interview.

\subsubsection{Franchisor leadership}

The concept of franchisor leadership emerged following discussion with franchisors, and was further explored with franchisees in both cases. Franchisee participants described leadership with words such as 'forward vision', 'innovative', 'trying to keep ahead of the game', 'progressive', 'thinking outside the square' and being 'right at the front when it comes to introducing these new sorts of technology' (CS2 Franchisor 4). Conversely, franchisors characterised the concept as 'showing ... leadership and maturity' and 'strategic direction', and bringing with it 'an expectation ... to come up with the initiatives, the strategies and then go back to them' (CS2 Franchisor 2). According to one participant:

I think franchisees join the systems to be led and to be, hopefully, better than their competitors ... So taking a position of leadership in an area that they possibly do not have expertise or knowledge in, but certainly have strong views about (i.e., e-commerce), was important to get buy-in ... And if you are showing your leadership and maturity to launch something that is going to grow the market and not erode it, I don't think you will get too many franchise partners that will stand in the way. (CS2 Franchisor 1)

Further, experts in this study consistently supported the contention that strong leadership was needed to further develop innovations of a strategic nature, such as ecommerce integration into a traditional franchise system. One expert noted that franchisees would expect a franchisor 'to provide that leadership, but sometimes it is just not 
forthcoming' (Expert 1). In addition, he explained that in cases where the franchisor did not have the resources to implement ecommerce or had not prioritised this matter, the franchisees had decided to take their actions regarding ecommerce and go 'off and [do] their own thing, with their little websites here and there, and Gumtree and eBay, and things like that' (Expert 1). However, this can ultimately damage the integrity of the franchise brand.

\subsection{Communication and collaboration with franchisees}

Communication was another important theme in this study noted to reduce fear and anxiety in franchisees (thus, supporting the findings of prior research) (Kremez, 2015). Clarity and consistency of communication were also highlighted as important factors for reducing franchisees' fear of the unknown and for gaining franchisee acceptance of change strategies. Indeed, extant research findings suggest that several elements influence the quality of the franchise relationship, including effective communication, which is critical for ensuring both trust and commitment, in turn (Watson \& Johnson, 2010).

Different strategies and media were sought within franchise networks to communicate with franchisees when introducing ecommerce on two distinct levels: (a) the FAC level and (b) the whole franchise network level. Here, FAC was regarded as a representative body of franchisees with substantial power in the franchisor-franchisee relationship. At this level, the communication style was more collaborative and inclusive, whereas at the network level, a power imbalance was more evident and the communication strategy followed a top-down approach. That said, franchisees still had their questions answered and concerns clarified in both Cases 1 and 2 (see Table 3). 
Table 3: Summary of Communication Methods

\begin{tabular}{lll}
\hline & Case 1 & Case 2 \\
\hline $\begin{array}{l}\text { (a) FAC/selected group of } \\
\text { franchisees }\end{array}$ & $\begin{array}{l}\text { Regional/national meetings } \\
\text { Consultations/workshops } \\
\text { Experience working with } \\
\text { FAC }\end{array}$ & $\begin{array}{l}\text { FAC meetings and special } \\
\text { meetings }\end{array}$ \\
& $\begin{array}{l}\text { National conference } \\
\text { Intranet }\end{array}$ & $\begin{array}{l}\text { National convention } \\
\text { Intranet } \\
\text { network }\end{array}$ \\
Ongoing support & Ongoing support \\
\hline
\end{tabular}

One of the franchisees interviewed described different modes and media of communication:

Oh, you know, [the franchisor] had meetings and I think I flew to [name of city] for one of them. They had consultations. They talked about it at the conference. They networked with a selected group of the franchisees, the FAC. So they do communicate what they wanted to do. We might not always understand the full picture. You might not always believe that it's gonna work. You might think, 'oh my God, that's gonna take all our business'. But it hasn't. (CS1 Franchisee 2)

In both cases, the strategy went through an extended process of negotiation and refinement, with franchisees 'involved in that process right from the beginning through to the end' (CS1 Franchisee 3). However, respondents who were also proactive business owners were not always seeking participation. For example, CS1 Franchisor 4 stated that they 'generally go with the flow, to be perfectly honest', and further explained that he trusted the CEO and that his work was confined to the local level—here, the franchisor's responsibility was instead designated to tackling the global perspective. In contrast, other franchisees expressed that more input from a wider selection of fellow stakeholders should have been sought to optimise the change process. 


\subsubsection{Communication at the franchise network level}

One of the strategies for communication at the whole network level (with supposed effect in both cases) regarded a special process during a national franchise conference. This provided an efficient way to present and gather information in a large group setting (i.e., containing more than 100 people in one room). The process involved encouraging franchisees to ask questions, writing them down as a record and then providing a response. This practice helped the franchisees feel safer about change and reduced their fears.

In both cases, the launch of an ecommerce strategy to franchisees occurred at the national conference, and was described similarly by participating franchisors:

There were a lot of questions based on the fact that they did not understand entirely what was proposed. We spent a lot of time clarifying how exactly it was meant to work ... So what we did is we collated all [the] questions from franchisees, which ended up being about 41 questions, I think. And the questions were about the strategy, operational questions, the rationale for the [financial] model ... All those sorts of questions. It was all about clarifying the model and how it would work in reality_ just enabling them to ask all the questions about 'why this' and 'why that'. (CS1 Franchisor)

Similarly, Case 2 also used the national conference to inform franchisees about the new ecommerce system:

Once a year we bring all of our franchise partners together for our annual convention where we are very much focused on education and other initiatives. But we made a dedicated session on how we were going to tackle ecommerce. So, [in an] open forum any questions could be asked: 'here is the website, here are the products, here is the pricing, this is how the model works, this is how an order will work, and this is how your dollars will redistribute back to you'. So, 
we actually took it one step further than our advisory council and addressed each of our franchise partners directly at our national convention. (CS2 Franchisor 1)

Evidently, communication, as a key component of any relationship, is a vital component of any change process. A framework for franchisee engagement in change is proposed where communication forms an integral part therein. The framework best describes how communication can be practically applied to achieve goals for franchisor-franchisee collaboration and subsequently foster healthy relationships in a system with asymmetrical control.

\subsubsection{Communication at the FAC level: FAC's crucial role in the consultation process}

When important strategic decisions are made that affect customers and franchisees, considering the latter's perspective is of paramount importance because (first and foremost) the ecommerce model must work operationally for both business owners and staff at the shopfront. Obtaining feedback from franchisees was critical for the success of this innovation, as they are interfacing with customers daily. Therefore, there must be a mechanism in place to assist franchisor and franchisee collaboration and create solutions that benefit the system as a whole. One way of enacting partnership was through the FACs, which are advisory bodies of elected franchisees that large and mature franchise networks normally have in place. However, as expert bodies on operational aspects, and not marketing or finance, they may not be suited to address complex issues such as ecommerce.

A prominent theme that emerged during research was that FACs were instrumental in ensuring that franchisees were heard and their feedback was considered, and that franchisees at large were represented when important strategic matters were being decided within the group. Both cases had a strong and an effective FAC. According to the Franchising Australia 2012 survey (Frazer et al., 2012), only 48 per cent of Australian franchise networks had an advisory council, and not all of them were set-up to work at their best capacity in serving a 
brand and franchisor-franchisee relations. Therefore, the cases presented here, although not typical, represent exemplars in the franchising community in terms of the nature and operation of their FACs. They also exercised the choice to showcase their FAC structure and processes in this research. For example, according to one franchisor:

our advisory council is a group of five or six elected representatives that we use to bounce new ideas, discuss concerns, etc. And for us, it means hearing the voice of the collective as opposed to hearing the voice of an individual. It changes every year in terms of membership, and it also matured over the years in terms of its value to both franchise partners and the organisation. (CS2 Franchisor 1)

Evidently, an advisory council confronts the general business overview and its expertise is mainly within the operational domain. Ecommerce crosses over operations, marketing, logistics, finance and IT. Therefore, it requires additional knowledge in those other areas, which FAC may not possess. There are mechanisms of engaging experts in fields beyond council expertise, and they may be called either from the pool of franchisees or from the franchisor staff, or be an external expert with no affiliation. Hence, a prominent theme that emerged was the strength of the FAC in general, as well as its key role in forming strategy decisions, such as those investigated in this research:

I'm a strong believer of the Advisory Council ... [but] some of the franchisees think that the FAC is purely there to rubber stamp something that the franchisor has put in front of us-but it's not the case. There is quite a bit of debate that goes on, and sometimes heated debate. (CS1 Franchisee 3)

However, there did appear to be a 'disconnect' or information gap between FAC-level franchisees and general franchisee-level owners who had never participated in council meetings: 
Look, for me it was okay because I was-I'm on the Advisory Council, so I was quite privy to quite a lot of it. So I had a very good idea of what was happening. Sometimes it could be confusing for other people, and they may not have a full understanding of what sort of rigorous debate took place in the meeting. (CS2 Franchisee 2)

Both franchise companies had an FAC. Table 4 below summarises the descriptions of each advisory council in Cases 1 and 2.

Table 4: Description of the FAC for Case 1 and Case 2

\begin{tabular}{|c|c|c|}
\hline & FAC Case 1 & FAC Case 2 \\
\hline Year founded & 2006 & 2000 \\
\hline $\begin{array}{l}\text { Number of franchisee } \\
\text { members }\end{array}$ & 8-10 members & 5-6 members \\
\hline Term of service & Two years & Two years (by rotation) \\
\hline $\begin{array}{l}\text { Number of meetings } \\
\text { each year and their } \\
\text { format }\end{array}$ & $\begin{array}{l}\text { - Annual meetings and } \\
\text { additional meetings over } \\
\text { teleconference, if required }\end{array}$ & $\begin{array}{l}\text { - Meets face to face four times } \\
\text { a year; meets every month by } \\
\text { telephone (1-2 hour meetings) }\end{array}$ \\
\hline Level of FAC & $\begin{array}{l}\text { - Only national-level council; } \\
\text { no regional structures in } \\
\text { place }\end{array}$ & $\begin{array}{l}\text { - Regional-level council } \\
\text { - National-level council (each } \\
\text { with its chair) }\end{array}$ \\
\hline $\begin{array}{l}\text { Process and inclusion } \\
\text { of voices from the } \\
\text { general franchisee } \\
\text { community }\end{array}$ & $\begin{array}{l}\text { - Agenda goes out to the } \\
\text { whole group } \\
\text { - Any franchisee can put } \\
\text { forward a discussion point } \\
\text { for the agenda } \\
\text { - Any franchisee can contact } \\
\text { their FAC member to discuss } \\
\text { their ideas for submission at } \\
\text { an upcoming FAC meeting }\end{array}$ & $\begin{array}{l}\text { Each council meets once a } \\
\text { month; between two levels } \\
\text { they have fortnightly meetings } \\
\text { When expertise is needed } \\
\text { beyond the FAC, knowledge } \\
\text { is sought from either the pool } \\
\text { of franchisees, HO staff or } \\
\text { external experts }\end{array}$ \\
\hline
\end{tabular}

\subsubsection{Framework for franchisee communication and participation}

In relation to franchisee engagement in change and innovation projects, both cases followed a multi-level process in which franchisees were involved in every stage of ecommerce implementation. Participation was implemented through each respondents' respective FAC. Although none of the cases utilised a project team for working on development and 
implementation of ecommerce into the business model, in both cases the franchisors and some franchisees reflected that a special purpose group would be a preferable instrument. Interviewees concurred that such a group would have been more effective and efficient in supporting an innovation project, particularly when its scope was beyond the FAC's competence (outside general day-to-day business and beyond the operations area). The participants described this group of people working together as an 'innovation team', a 'dedicated group of franchisees' or a 'special committee'.

This idea also confirms the findings from previous studies in which some of the franchise networks used project teams to work on ecommerce arrangements in the system (Kremez, 2015). This was generally reported as a very effective way of engaging interested and competent franchisees and other stakeholders or external advisors.

In this case study research, some franchisees suggested involving more parties, and not just the FAC members, in developing an ecommerce model. Accordingly, this would have facilitated early identification of certain issues in the process, thus, streamlining implementation. In addition, the framework that relies heavily on FAC support would only work if there were an effective advisory council in place. Since not all networks have an operational FAC (Frazer et al., 2012), it is important that the framework not only considers this discrepancy, but also proves effective, regardless of council presence. Moreover, smaller networks generally do not have an FAC but still require a process for seeking franchisee input into their decisions.

The experts interviewed also agreed that the use of a special group, referred hereafter as the project team, is most appropriate for addressing system-level problems of a strategic nature beyond the operational area of knowledge:

FACs are often very operationally focused. So, they will talk about how they can do Process A better or how they can get ... Supplier B to deliver on time, and 
things like that. They can also have significant input into marketing initiatives. And, of course, ecommerce crosses several of those things-it involves marketing, it involves operations, and it involves logistics. And that becomes a little bit complicated for an FAC to deal with. So, the FAC may say that we want to know what the franchisor wants to propose with regard to ecommerce, but the FAC will not have the answer. (Expert 1)

Further, inherent difficulties are still encountered with FAC support. Primarily, these councils may not be set-up to operate for the benefit of the system and, second, proper guidelines regulating FAC operation often have not been established, thus, preventing councils from efficiently fulfilling their role. Three experts in franchise consulting suggested that a project team should be used to address complex issues of this nature. They referred to this special purpose group in different ways, either as a 'working group' (Expert 1), 'taskforce' (Expert 2) or a 'subcommittee' (Expert 5). The rationale for using a project team concerns a situation in which the issue under consideration is beyond FAC expertise and requires knowledge in several areas other than operations. The composition of a project team will also depend on the nature of a project and may involve franchisees, franchisor staff, external experts and even clients. According to Expert 1, 'this working group will consist of franchisees who are more savvy in these things than others'. The life span of the project team then depends on achieving the goals created prior to commencement:

I think the working group has got a finite life. It is very much project-focused. For example, here's the ecommerce policy, here comes the development of the platform that supports that policy, here's the execution or the rollout of that platform. Then, I think once it is adopted and has a certain level of usage across the [franchise] group, then the working group has done what it set out to do. The ongoing management thereafter or the ongoing responsibility for it can be passed 
back to the franchisor with ongoing input from the FAC. But the working group is a special purpose group. (Expert 1)

I'd make it a taskforce. I think bringing it to FAC meetings is a bit general. I think a taskforce would work better, as people are focused on a specific question. (Expert 2)

In situations in which a franchise network has an FAC in place, a project team would be formed with council assistance and endorsement. One expert in this study was involved in a project team and chaired the 'subcommittee' dedicated to the creation of an ecommerce strategy. He described the case, as follows:

In one case, part of the strategy was [that] there was a very progressive franchisor [and] the issue was raised; it was discussed, it was broken down to a working party: a subcommittee. The subcommittee went and got other franchisees involved. Certain research was done. Certain modelling was undertaken. And then it was brought back to the FAC who had several discussions around what it should be. So it was a very good sort of structure ... When the FAC endorsed the final one, basically it went out for comment to the larger group and several state meetings were held to explain in detail how it was going to go. (Expert 5)

In summary, based on the interview results, the researchers developed a framework for optimal franchisee engagement in change and innovation projects. Consistent with the main findings presented in previous sections, the framework highlights the key role of advisory councils and further presents the process on different levels - from the franchisor level to the FAC level, and through to an individual franchisee level, including how and at what stage those levels have input towards the end goal (see Figure 1). More specifically, we identify 
eight steps that are crucial for setting up an effective process for franchisee engagement in change and innovation:

1. Identify the issue for the system, where 'issue' denotes the strategic and ongoing nature of engagement, which is associated with change and innovation of some sort that is not purely operational. (Ongoing strategic matters that are limited to operations can be dealt with by the FAC, provided it is effective.)

2. The franchisor develops a basic strategy line (or several strategies or approaches) for discussion with franchisees.

3. Rigorous dialogue of the strategy or strategies is guided between the FAC and franchisor, where franchisee FAC members lead the discussion. Various tools can be used to maintain a constructive tone. If there is no FAC or if the FAC is dysfunctional, then the project teams can be created at this point.

4. Decisions are made around the composition of a project team (if deemed necessary), including evaluation of the need to involve external experts.

5. The project team is formed and consists of franchisees with expertise in the subject matter, franchisor staff members with relevant knowledge and experts (if needed). This group works on the relevant issue and forms one or several solutions.

6. Outcomes of the project team's work are communicated to the entire network (after gaining approval from the franchisor). These are presented by the chair of the project team (preferably a franchisee rather than a member of the franchisor's team).

7. Outcomes and solutions are incorporated into the initial strategy, provided there is adequate feedback from the franchise group as a whole.

8. The project team is dissolved if there is unanimous agreement that its goals have been achieved and no further work and refinement are required. 
Essentially, this framework builds on the reflective process from leading franchise groups in Australia that are constantly improving their systems and innovating to ensure a high level of franchisee satisfaction and quality franchisor-franchisee relationships. Also, it reflects expert opinion on successful franchisee engagement, informed by practical consulting experience. The framework crosses over communication, participation and franchise relations, which represent concepts that are cornerstone elements of this research. The approach adopted in this structure-wherein franchisee input is sought for creating an ecommerce strategy or in making another important decision within the franchise network-reinforces arguments in the existing literature. Indeed, White (2010) maintained that the basis of franchise relationships as a whole is determined by the culture of the franchise system towards franchisee participation in decision-making, as well as leadership in the franchisee community. Although the unique relational structure between franchisees and franchisors does lend itself to difficulties in strategy creation (White, 1998, 2010), those systems that build the foundations for constructive relations with franchisees (and further include their input into the strategy) have a higher chance of succeeding in the long term. 


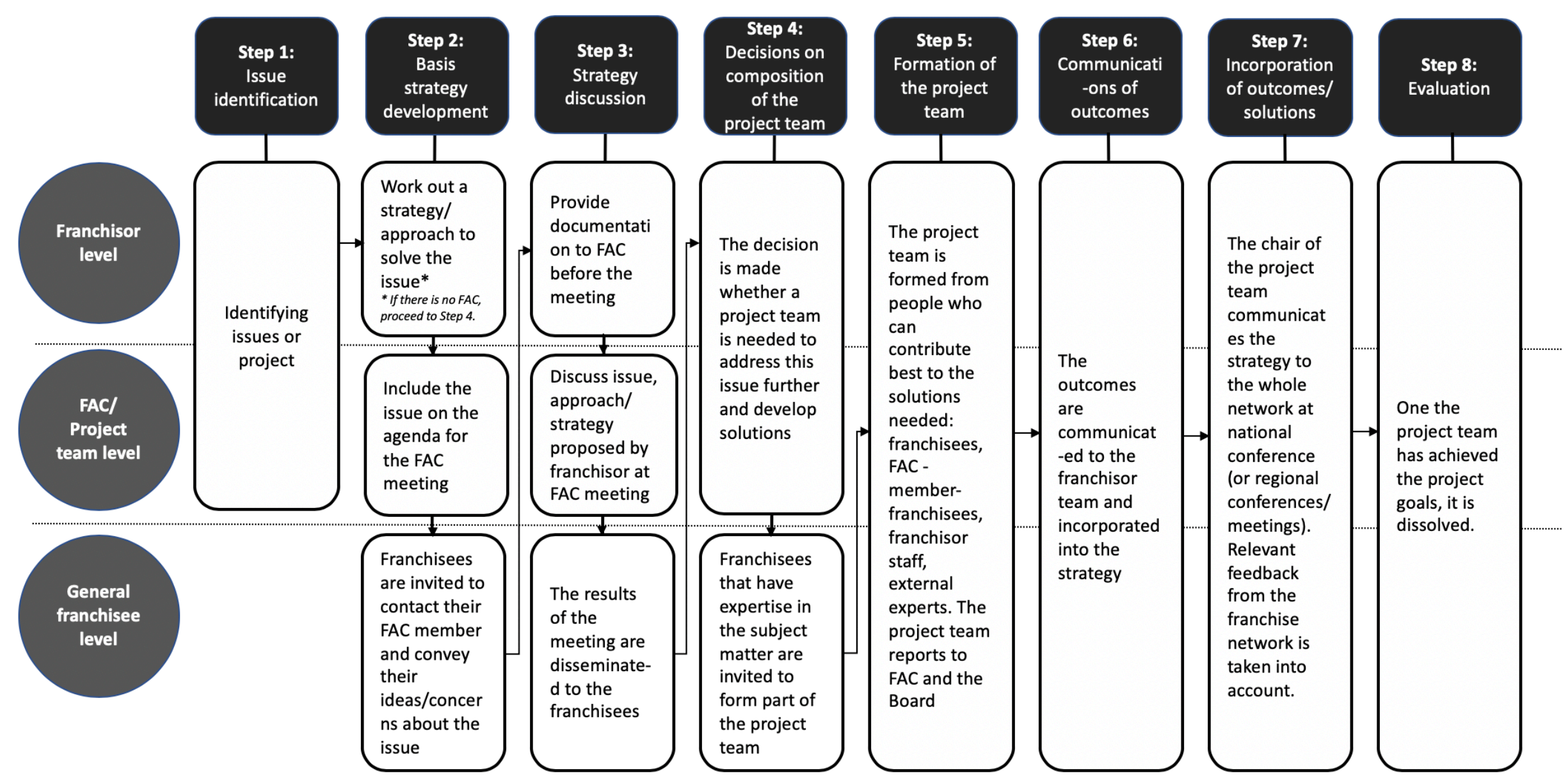

Figure 1. Framework for franchisee engagement in change and innovation. 


\subsection{Training and support}

Training is an integral part of the change initiative in any organisation, and-especially in a franchise system-serves to make sure that it is disseminated and implemented correctly throughout the network. However, should franchisees not receive adequate training, any innovation, however beneficial it may be for the system, may contribute to failure. Therefore, it is important to ensure that the relevant training and support structures are in place before introducing change in a franchise network. As such, this section discusses the findings on both cases' training and support initiatives for franchisees when ecommerce was introduced into their respective business model.

\subsubsection{Case 1}

In Case 1, the franchisor used a training night to introduce a basic overview of the online service system. The support structure was created, and any questions could be fielded with individual concerns resolved. The support structure included (1) a comprehensive intranet website with all the procedures arranged, (2) a dedicated customer service staff member to help with the 'online' side of the franchisees' businesses, and (3) field support managers assisting franchisees with this aspect of operation.

As CS1 Franchisor explained, the purpose of the training and support structures helped franchisees to learn about the ecommerce system:

We had a training night where they learned the new system, the way it fitted the business model and into the marketing. So we trained them on the product positioning, marketing, as well as being able to help, transact and deal with customers about it all. We knew it was not going to be enough, but it gave them an overview.

Second, support structures were implemented to assist franchisees if they had questions pertaining to the ecommerce system: 
We then turned these things into procedures to put on our intranet, and we also have in the office here a dedicated customer service person to help with 'online'

... We also have our field support managers that have assisted them as well.

(CS1 Franchisor)

Franchisors indicated that the technology was easy to use and all the relevant information was provided through the intranet to franchisees. However, there were still some who needed extra assistance: 'It's just those who have not embraced it; we still need to hold their hands' (CS1 Franchisor).

There was diversity between franchisees' perspectives on the adequacy and appropriateness of training and support provided around the time of launching an ecommerce system into their network. Some felt that the training was insufficient: 'It was there; it was basic. It was just the evening session: "This is what it is?" A few screenshots, and "go ahead and try it out". Do you know what I mean? It could have been much better' (CS1 Franchisee 1). Others confirmed that the support structure was there when needed:

In my view, [franchisor] does provide a really good support structure. They're not a franchisor who will be knocking on your door every day or every week, but if you need them they're there, and they've got the right people to help you through any issues you have. (CS1 Franchisee 3)

\subsubsection{Case 2}

Similar to Case 1, the ecommerce platform in Case 2 was launched at an annual conference where the details were explained to all franchisees. However, technical features were not discussed at that point. A strong support structure was also provided, which included (1) an intranet website with procedures, and (2) support staff members at the franchisor's office to guide franchisees through an online transaction. 
Although during the launch the franchisor did not delve into technical details about the system, strong support structures were provided to facilitate the franchisees' learning. The franchisor was able to provide 'one-on-one hand-holding' (CS2 Franchisor 1) in the training process, as franchisees would not usually receive online orders every day:

So when a franchise partner received an order, we would call them and take them through. Because it is their first time in doing an order like this, we would refresh their memory, remind them what the deal was, and remind them how they needed to handle the transaction. So, in effect, we trained them on the fly, would be the best way to describe it. (CS2 Franchisor 1)

Importantly, individualised support was kept in place two years after implementation of the ecommerce platform to alleviate any concerns arising from the management of online orders. As CS2 Franchisor 2 explained, 'I generally will follow up a franchise partner with a phone call if it's a big order or if it's an unusual order, just to make sure that we're seeing the customer through that journey in the right way'.

From the franchisee point of view, there was certainty that support was there when needed as well as information on the intranet: 'Definitely plenty of people in the head office that we can always talk to if we've got questions or go with our concerns. Definitely easy to find the information if we wanted, or speak with someone' (CS2 Franchisor 3). However, the system was not fully automated, which had associated disadvantages. For example, orders were not being forwarded to the nearest franchisee promptly, for which the support staff at the franchisor's office were made responsible (Table 5). 
Table 5: Summary of Training and Support for Case 1 and Case 2

\begin{tabular}{|c|c|c|}
\hline & Case 1 & Case 2 \\
\hline $\begin{array}{l}\text { Overall } \\
\text { description }\end{array}$ & $\begin{array}{l}\text { - Franchisor used a training night } \\
\text { where a basic overview of the } \\
\text { online service system was given } \\
\text { The support structure was created } \\
\text { and included: } \\
\text { (1) a comprehensive intranet } \\
\text { website with all the procedures } \\
\text { (2) a dedicated customer service } \\
\text { staff member to help with the } \\
\text { 'online' side of franchisees' } \\
\text { businesses } \\
\text { (3) field support managers assisting } \\
\text { franchisees with this aspect of } \\
\text { their business. }\end{array}$ & $\begin{array}{l}\text { - Ecommerce was launched at } \\
\text { an annual conference } \\
\text { - Technical details were not } \\
\text { discussed at that point } \\
\text { - A strong support structure } \\
\text { was provided and included: } \\
\text { (1) intranet website with } \\
\text { procedures } \\
\text { (2) a support staff member } \\
\text { at the franchisor's office } \\
\text { to guide franchisees } \\
\text { through online } \\
\text { transactions. }\end{array}$ \\
\hline $\begin{array}{l}\text { Franchisor } \\
\text { perspective }\end{array}$ & $\begin{array}{l}\text { - Adequate training and information } \\
\text { was provided during the training } \\
\text { night } \\
\text { - } \quad \text { Relevant support structures were } \\
\text { provided as a follow-up } \\
\text { - Franchisees who need ongoing } \\
\text { support with the system are those } \\
\text { who have not yet embraced it }\end{array}$ & $\begin{array}{l}\text { Basic training about the } \\
\text { system at the annual } \\
\text { conference } \\
\text { - Strong one-on-one support } \\
\text { during the first online } \\
\text { transaction, as well as some } \\
\text { subsequent unusual ones }\end{array}$ \\
\hline $\begin{array}{l}\text { Franchisee } \\
\text { perspective }\end{array}$ & $\begin{array}{l}\text { - Training was basic but sufficient } \\
\text { - }\end{array}$ & $\begin{array}{l}\text { - Training was adequate } \\
\text { - The support structure was } \\
\text { adequate and highly } \\
\text { individualised } \\
\text { - Disadvantages of the } \\
\text { manual system were evident } \\
\text { in some orders not being } \\
\text { passed on promptly }\end{array}$ \\
\hline
\end{tabular}

\subsection{Proposed model}

A conceptual model for introducing change into franchise networks was developed, based on this research (see Figure 2). This can serve for further study and hypothesis testing. The model proposes that resistance to change, change readiness and franchise acceptance are important determinants of success, consistent with existing literature on organisational change (Elving, 2005). Essentially, two main factors can affect change outcomes: franchise relationships and communications. 
First, it is proposed that a healthy franchise relationship (Davies et al., 2011; White, 2010; Wright \& Grace, 2011) can decrease resistance to change and contribute to franchisee acceptance and overall readiness. In fact, Grace, Frazer, Weaven and Dant (2016) found that the quality of the franchise relationship is influenced by positive organisational culture and perception of franchisor competence and integrity. These factors are particularly critical for ensuring trust- and commitment-based partnerships between franchisors and franchisees in the long term.

Second, clear, consistent and effective communication is the cornerstone for success. When undertaken successfully, communication can increase readiness for change, decrease resistance to change and enhance franchise acceptance. Communication during the change process can also be conducted with two purposes in mind: inform (through the provision of training and education) and create community spirit (through engagement in decisionmaking) (Elving, 2005). In other words, effective communication in this framework refers to communication that prioritises relationships with franchisees by engaging them in decisionmaking, and providing appropriate and adequate training and education regarding the subject of change. The two core aspects of franchisee engagement within strategy-making are (1) using the project team approach to seek franchisee input, and (2) maintaining clear and consistent communication with the entire franchise network about change. 


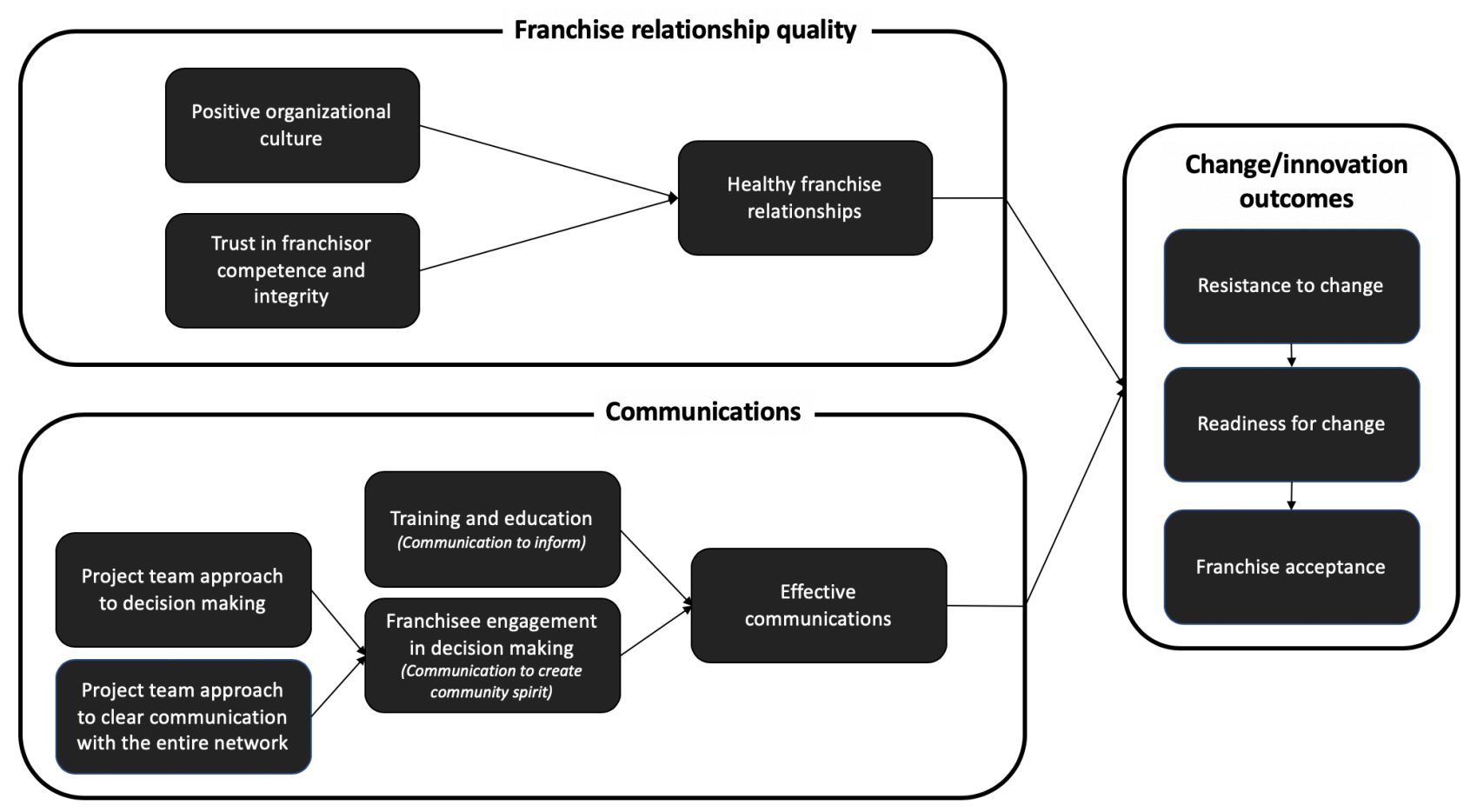

Figure 2. A model for franchisee acceptance, readiness for change and effective communication in the franchise network.

\section{Implications and future research directions}

\subsection{Implications for the franchise sector}

This research has reinforced the literature on franchise relationships and further found that franchisees generally perceive franchisor leadership as one of the key aspects in facilitating the transition required for implementing ecommerce in their networks. Indeed, Watson and Johnson (2010) found evidence that 'listening and mutual respect between franchisor and franchisees provide the foundation for a successful franchise system' (p. 63); thus, they suggest that this can be achieved through a compassionate leadership style.

Moreover, franchisees in this research specifically alluded to the personality, experience or the skill set of their CEO or another senior franchisor team member involved in the development and implementation of an ecommerce strategy, where leadership (in this sense) seemed to influence franchisee perceptions about the relationship in general. This finding augments the literature, affirming that franchisor-franchisee relations seem to be an 
individual-to-individual (franchisor, CEO, etc.) relationship, rather than an individual-tocollective (franchise firm, franchisor team) relationship. Indeed, this is unsurprising because franchisors play a key role in evolving organisational culture and communicating the franchise vision. Although Watson and Johnson (2010) found this to be true in small franchise firms - proposing that it may not be the case for bigger businesses because of the organisational complexity pertinent to large systems - this study noted the same perceptions from franchisees (regarding franchisor leadership), where the role of the franchisor remains very important in motivating franchisees and communicating organisational vision.

Franchising professionals could also learn several key lessons from this research. First, franchisors should involve franchisees in developing their system's ecommerce strategies. Second, communication about forthcoming change and implementation should be timely, clear, consistent and regular, and underpinned by transparency and mutual benefit of the franchisor and the franchisees involved, while maintaining realistic time lines.

Both groups' perspectives need also be considered if a franchising relationship is to work as a genuine partnership. As encroachment is a sensitive issue and ecommerce embodies such an important strategic decision, unilateral action by the franchisor could potentially limit cooperation and have an overall negative effect on franchisor-franchisee relations (Hellriegel \& Vincent, 2000). For franchisors integrating ecommerce into an existing system (that was not initially designed to incorporate the effect of online sales on franchisee territories), the optimal approach for developing a successful policy and strategy is to work collaboratively with franchisees (Terry, 2002). Their involvement in this development process can also benefit franchisor-franchisee relations in general (Abell \& Scott, 2000; Hellriegel \& Vincent, 2000). Alternatively, franchisors who exclude franchisees entirely from decisions around ecommerce could even face legal action if they are violating franchise or competition laws (Abell \& Scott, 2000). 
In summary, from the interviews conducted with franchise practitioners, certain practical recommendations can be made that will service the franchise sector:

1. For any innovation in the franchise network, involve the franchisees as early as possible in the process of generating ideas. Franchisors may need to pay closer attention to the collegial structures, such as FACs and project teams that allow for franchisee input into strategy creation. Participation of franchisees in the strategy may be beneficial and necessary to ensure successful implementation of change in general. Such a process may also assist in fostering franchisee trust (Grace et al., 2016). Having an effective process in place in which franchisee feedback can be sought, analysed and actioned may support franchise networks to be more resilient and further promote superior franchisor-franchisee relations.

2. It is important to be as clear and consistent as possible in franchisor-to-franchisee communication. This may be helpful to use a big event, such as an annual franchise conference, to explain a new strategy or innovation to franchisees. Clarity and consistency of communication were found to be important factors in reducing franchisees' fear of the unknown and for gaining franchisee acceptance of the strategy. Problems in franchisee-franchisor relationships are often located in the area of perceived rights and expectations; therefore, clearer communication (including the language used in legal documents) may help to avoid potential conflict.

3. The language in a franchise agreement has to be unambiguous, and franchisee rights have to be stated very specifically. This can alleviate misunderstandings and conflicts that arise between parties in the future. Franchisors and franchisees might consider using relational contracts that are 'constructed incomplete intentionally so the contracting parties have room to manoeuvre', but remain 'very clear on how the contract begins and how to back out from it' (Rosado-Serrano \& Paul, 2018, p. 4). 
Indeed, they might be more suitable to regulate trust- and commitment-based franchise relationships.

4. The value of quality training and support services to franchisees is supported by extant research, where such services as staff training, software ordering, telephone assistance, point of sale and franchise councils were associated with less disruption to a system's functioning (Grünhagen, DiPietro, Stassen \& Frazer, 2008). Here, Watson and Johnson (2010) also found a link between the quality of training and support services offered by the franchisor and overall company success.

\subsection{Further research directions}

Although this paper focused on franchisor ecommerce, the framework and model developed here can be applied beyond these settings, such as to any major change initiatives occurring within a franchise or when a key decision is to be made. The underlying principles can be effected broadly to the area of franchise relationships. Further research can also attempt to address issues related to other stakeholders such as franchisee unions. In addition, it is recommended that future studies extend the research by exploring the findings through different theoretical lenses, such as the application of relational contract theory in franchise agreements (e.g., Rosado-Serrano \& Paul, 2018). This could lead to a theoretical contribution to the body of literature about the nexus between ecommerce and franchising, where scholars agree that empirical research remains limited.

\section{References}

Abell, M., and Scott, A. (2000). The e-commerce challenge for franchising. Managing Intellectual Property, (101), 34-37.

Altinay, L., \& Brookes, M. (2012). Factors influencing relationship development in franchise partnerships. Journal of Services Marketing, 26(4), 278-292. 
Altinay, L., Brookes, M., Madanoglu, M., \& Aktas, G. (2014). Franchisees' trust in and satisfaction with franchise partnerships. Journal of Business Research, 67(5), 722-728.

Chaparro-Peláez, J., Agudo-Peregrina, Á. F., and Pascual-Miguel, F. J. (2016). Conjoint analysis of drivers and inhibitors of e-commerce adoption. Journal of Business Research, 69(4), 1277-1282.

Chau, S. (2003). The use of e-commerce amongst thirty-four Australian SMEs: an experiment or a strategic business tool?. Journal of Systems and Information Technology, 7(1/2), 49-66.

Choshin, M., and Ghaffari, A. (2017). An investigation of the impact of effective factors on the success of e-commerce in small-and medium-sized companies. Computers in Human Behavior, 66, 67-74.

Chumnumpan, P., and Shi, X. (2019). Understanding new products' market performance using Google Trends. Australasian Marketing Journal (AMJ). doi.org/10.1016/j.ausmj.2019.01.001

Cliquet, G., \& Voropanova, E. (2016). E-commerce and encroachment: evidence from French franchise networks. Journal of Marketing Channels, 23(3), 114-128.

Coch, L., \& French Jr, J. R. (1948). Overcoming resistance to change. Human relations, 1(4), $512-532$.

Cui, M., \& Pan, S. L. (2015). Developing focal capabilities for e-commerce adoption: A resource orchestration perspective. Information \& Management, 52(2), 200-209.

Davies, M. A., Lassar, W., Manolis, C., Prince, M., and Winsor, R. D. (2011). A model of trust and compliance in franchise relationships. Journal of Business Venturing, 26(3), $321-340$.

De Ridder, J. A. (2004). Organisational communication and supportive employees. Human Resource Management Journal, 14(3), 20-30. 
Dennis, C., Merrilees, B., Jayawardhena, C., and Tiu Wright, L. (2009). E-consumer behaviour. European Journal of Marketing, 43(9/10), 1121-1139.

Di Fatta, D., Patton, D., and Viglia, G. (2018). The determinants of conversion rates in SME e-commerce websites. Journal of Retailing and Consumer Services, 41, 161-168.

Dixon, H., \& Quinn, B. (2004). Franchising and the Internet: an exploratory study of franchisor Web sites. Internet Research, 14(4), 311-322.

Dixon, H., and Quinn, B. (2004). Franchising and the Internet: an exploratory study of franchisor Web sites. Internet Research, 14(4), 311-322.

Dorward, L. J., Mittermeier, J. C., Sandbrook, C., \& Spooner, F. (2017). Pokémon Go: benefits, costs, and lessons for the conservation movement. Conservation Letters, 10(1), 160-165.

Dubois, A., and Gadde, L. E. (2002). Systematic combining: an abductive approach to case research. Journal of business research, 55(7), 553-560.

Eisenhardt, K. M. (1989). Building theories from case study research. Academy of Management Review, 14(4), 532-550.

Elving, W. (2005). The role of communication in organisational change. Corporate Communications: An International Journal, 10(2), 129-138.

Elving, W. J. (2005). The role of communication in organisational change. Corporate communications: an international journal, 10(2), 129-138.

Emerson, R. W. (2010). Franchise Encroachment. American Business Law Journal 47(2): 191-290.

Frazer, L., Weaven, S., and Bodey, K. (2012). Franchising Australia 2012. Brisbane: Griffith University.

Frazer, L., Weaven, S., and Grace, A. (2014). Franchising Australia 2014, Brisbane, Australia: Asia-Pacific Centre for Franchising Excellence, Griffith University. 
Gold, M. E. (1999). The complete social scientist: A Kurt Lewin reader. American Psychological Association.

Grace, A. R., Frazer, L., Weaven, S. K., and Dant, R. P. (2016). Building franchisee trust in their franchisor: insights from the franchise sector. Qualitative Market Research: An International Journal, 19(1), 65-83.

Grünhagen, M., Di Pietro, R. B., Stassen, R. E., and Frazer, L. (2008). The Effective Delivery of Franchisor Services: A Comparison of U.S. and German Support Practices for Franchisees. Journal of marketing Channels, 15(4), 315-335.

Hellriegel, J. E., and Vincent, W. S. (2000). The Encroachment Handbook, The Problem, The History, The Solution. Paper presented at the 14th Conference of the International Society of Franchising, San Diego.

Holt, D. T., Armenakis, A. A., Feild, H. S., \& Harris, S. G. (2007). Readiness for organizational change: The systematic development of a scale. The Journal of applied behavioral science, 43(2), 232-255.

Hua, N., Hight, S., Wei, W., Ozturk, A. B., Zhao, X., Nusair, K., \& DeFranco, A. (2019). The power of e-commerce: Does e-commerce enhance the impact of loyalty programs on hotel operating performance?. International Journal of Contemporary Hospitality Management.

Huberman, A. M., and Miles, M. B. (1994). Data management and analysis methods. In N. K. Denzin and Y. S. Lincoln (Eds.), Handbook of qualitative research (pp. 428-444). Thousand Oaks, CA: SAGE Publications.

Kaushik, K., Mishra, R., Rana, N. P., and Dwivedi, Y. K. (2018). Exploring reviews and review sequences on e-commerce platform: A study of helpful reviews on Amazon. in. Journal of Retailing and Consumer Services, 45, 21-32. 
Knack, G. L. and A. K. Bloodhart (2001). Do Franchisors Need to Rechart the Course to Internet Success. Franchise Law Journal 20, 133-147.

Kotter, J. P. (1995). Leading change: Why transformation efforts fail. Harvard business review 73, 59-67.

Kotter, J. P. (1996). Leading change. Boston, MA: Harvard Business School Press. Kouzes, JM, \& Posner, BZ (2002). The leadership challenge. San Francisco, CA.

Kremez, Z. (2015). The Effects of E-commerce on Franchising: An Exploratory Australianbased Study. Paper presented at the International Society of Franchising (ISoF) Conference, Oviedo, Spain.

Kremez, Z., Frazer, L., \& Thaichon, P. (2019). The effects of e-commerce on franchising: Practical implications and models. Australasian Marketing Journal (AMJ).

Kremez, Z., Frazer, L., and Thaichon, P. (2019). The effects of e-commerce on franchising: Practical implications and models. Australasian Marketing Journal (AMJ). doi.org/10.1016/j.ausmj.2019.04.002

Lee, K. J. (2017). Knowledge sharing in franchise system: franchisee self-leadership, satisfaction, and compliance. International Journal of Contemporary Hospitality Management, 29(12), 3101-3118.

Lewin, K. (2016). Frontiers in group dynamics: Concept, method and reality in social science; social equilibria and social change. Human relations, 1, 3-41.

ltinay, \& Brookes (2012), Rosado-Serrano et al. (2018), and Rosado-Serrano, A., \& Paul, J. (2018).

Mason, R. B. (2007). The external environment's effect on management and strategy: a complexity theory approach. Management decision, 45(1), 10-28. 
McKay, K., Kuntz, J. R., \& Näswall, K. (2013). The effect of affective commitment, communication and participation on resistance to change: The role of change readiness. New Zealand Journal of Psychology (Online), 42(2), 29-40.

Merriam, S. B., and Tisdell, E. J. (2015). Qualitative research: A guide to design and implementation. John Wiley and Sons.

Miles, M. B., Huberman, A. M., Huberman, M. A., and Huberman, M. (1994). Qualitative data analysis: An expanded sourcebook. sage.

Nelissen, P., \& van Selm, M. (2008). Surviving organizational change: how management communication helps balance mixed feelings. Corporate Communications: An International Journal, 13(3), 306-318.

Nisar, T. M., and Prabhakar, G. (2017). What factors determine e-satisfaction and consumer spending in e-commerce retailing?. Journal of Retailing and Consumer Services, 39, 135-144.

Perrigot, R., \& Pénard, T. (2013). Determinants of e-commerce strategy in franchising: A resource-based view. International Journal of Electronic Commerce, 17(3), 109-130.

Perrigot, R., and Pénard, T. (2013). Determinants of e-commerce strategy in franchising: A resource-based view. International Journal of Electronic Commerce, 17(3), 109-130.

Perrigot, R., Basset, G., and Cliquet, G. (2017). E-commerce opportunities and challenges for franchise chains. In Handbook of Research on Franchising. Edward Elgar Publishing.

Perrigot, R., Basset, G., Briand, D., \& Cliquet, G. (2013). Uniformity in franchising: A case study of a French franchise network with several franchisees having their own website. Journal of marketing Channels, 20(1-2), 99-119.

Peterson, A., \& Dant, R. P. (1990). Perceived advantages of the franchise option from the franchisee perspective: Empirical insights from a service franchise. Journal of Small Business Management, 28(3), 46. 
Quach, T. N., Thaichon, P., and Jebarajakirthy, C. (2016). Internet service providers' service quality and its effect on customer loyalty of different usage patterns. Journal of Retailing and Consumer Services, 29, 104-113.

Rao, S. and L. Frazer (2010). The use of Internet-based technologies in Australian franchise systems: A preliminary study. Journal of Internet Business 2, 1-35.

Rao, S., and Frazer, L. (2010). The use of Internet-based technologies in Australian franchise systems: A preliminary study. Journal of Internet Business, 2(0), 1 - 21.

Rosado-Serrano, A., \& Paul, J. (2018). A new conceptual model for international franchising. International Journal of Hospitality Management, 75, 179-188.

Rosado-Serrano, A., Paul, J., \& Dikova, D. (2018). International franchising: A literature review and research agenda. Journal of Business Research, 85, 238-257.

Shah Alam, S. (2009). Adoption of internet in Malaysian SMEs. Journal of Small Business and Enterprise Development, 16(2), 240-255.

Snowden, D. J., and Boone, M. E. (2007). A leader's framework for decision making. A leader's framework for decision making. Harvard business review, 85(11), 68-76, 149.

Stake, R. E. (1978). The case study method in social inquiry. Educational researcher, 7(2), 58.

Stake, R. E. (1994). Case Studies. In N. K. Denzin and Y. S. Lincoln (Eds.), Handbook of Qualitative Research (pp. 236-247). Thousand Oaks: SAGE Publications.

Tagashira, T., and Minami, C. (2016). The effects of online and offline information sources on multiple store patronage. Australasian Marketing Journal (AMJ), 24(2), 116-124.

Terry, A. (2002). The e-business challenge to franchising. Australian Business Law Review, $30(3), 227-241$. 
Terry, A. (2002). The e-business challenge to franchising. Australian Business Law Review, 30(3), 227-227.

Thaichon, P., Lobo, A., Prentice, C., and Quach, T. N. (2014). The development of service quality dimensions for internet service providers: Retaining customers of different usage patterns. Journal of Retailing and Consumer Services, 21(6), 1047-1058.

Thaichon, P., Weaven, S., Quach, S., Baker, B., and Frazer, L. (2019). What to expect after the honeymoon: evolutionary psychology of part-time franchising. Journal of Strategic Marketing, 1-25. doi.org/10.1080/0965254X.2019.1570315

Thaichon, P., Weaven, S., Quach, S., Bodey, K., Merrilees, B., and Frazer, L. (2018). Female franchisees; a lost opportunity for franchising sector growth?. Journal of Strategic Marketing, 1-16.

Tiku, N. (2018). Europe's New Privacy Law Will Change the Web and More. Wired Magazine, 30.

Timms, J., Frazer, L., Weaven, S., and Thaichon, P. (2019). Stay Ahead of a Game or Stay Still: The Impact of Learning and Development on Business Performance. In Subsistence Entrepreneurship (pp. 215-237). Springer, Cham.

Todnem By, R. (2005). Organisational change management: A critical review. Journal of change management, 5(4), 369-380.

Trinh, G. T., Anesbury, Z. W., and Driesener, C. (2017). Has behavioural loyalty to online supermarkets declined?. Australasian Marketing Journal (AMJ), 25(4), 326-333.

Wachter, S., \& Mittelstadt, B. (2019). A right to reasonable inferences: re-thinking data protection law in the age of big data and AI. Columbia Business Law Review.

Wang, W. T., Wang, Y. S., and Liu, E. R. (2016). The stickiness intention of group-buying websites: The integration of the commitment-trust theory and e-commerce success model. Information and Management, 53(5), 625-642. 
Watson, A., and Johnson, R. (2010). Managing the Franchisor-Franchisee Relationship: A Relationship Marketing Perspective. Journal of marketing Channels, 17(1), 51-68.

Watson, A., Kirby, D. A., \& Egan, J. (2002). Franchising, retailing and the development of ecommerce. International Journal of Retail \& Distribution Management, 30(5), 228 237.

Watson, A., Kirby, D. A., and Egan, J. (2002). Franchising, retailing and the development of e-commerce. International Journal of Retail and Distribution Management, 30(5), 228-237.

Weaven, S., Baker, B. L., Edwards, C., Frazer, L., and Grace, D. (2018). Predicting organizational form choice from pre-entry characteristics of franchisees. Australasian Marketing Journal (AMJ), 26(1), 49-58.

Weaven, S., Frazer, L., Brimble, M., Bodle, K., Roussety, M., and Thaichon, P. (2019). Encouraging Indigenous Self-Employment in Franchising. In Subsistence Entrepreneurship(pp. 69-87). Springer, Cham.

White, D. W. (1998). The impact of environmental uncertainty on strategy creation style in a franchise channel setting. Journal of Strategic Marketing Review, 6(4), 273-304.

White, D. W. (2010). The impact of marketing strategy creation style on the formation of a climate of trust in a retail franchise setting. European Journal of Marketing, 44(1/2), $162-179$.

Wright, O., and Grace, A. (2011). Trust and commitment within franchise systems: An australian and new zealand perspective. Asia Pacific Journal of Marketing and Logistics, 23(4), 486-500.

Wright, O., and McAuley, A. (2012). Australian franchising research: Review, synthesis and future research directions. Australasian Marketing Journal (AMJ), 20(2), 158-163. 
Wu, C. W. (2015). Antecedents of franchise strategy and performance. Journal of Business Research, 68(7), 1581-1588.

Yin, R. K. (2009). Case study research: design and methods. California: SAGE Publications.

Young, R., Frazer, L., Weaven, S., Roussety, M., and Thaichon, P. (2019). Work Hard, Play Hard: Work-Life Balance in Small Business. In Subsistence Entrepreneurship (pp. 195-213). Springer, Cham. 